\title{
Intrafamily Interaction and Desired Additional Fertility in Pakistan: A Simultaneous-Equation Model with Dichotomous Dependent Variables
}

\author{
M. ALI KHAN and ISMAIL SIRAGELDIN ${ }^{*}$
}

\begin{abstract}
In this paper we present a methodology for incorporating intrafamily interaction in the desire for additional children. The latter is formalized as a dichotomous dependent variable. Our methodology involves a generalization of the partial-adjustment hypothesis and an application of the two-stage estimators proposed by Mallar $[31 ; 32]$ and Heckman $[20 ; 21]$. We present empirical estimates based on 1968 data from Pakistan.
\end{abstract}

\section{INTRODUCTION}

It is by now a well known and standard criticism of the Chicago-Columbia approach [51] to fertility that it suffers from the assumption of a common utility function for the entire household. ${ }^{1} \quad$ Both Nerlove [42] and Griliches [19] discuss the conceptual difficulties involved in trying to formulate a utility function that takes into account the preferences of all the family members. An extended family system, as is prevalent in most of the LDCs, further aggravates the problems. In this paper we suggest a possible solution. ${ }^{2}$

* Dr. Khan is Professor in the Department of Political Economy, The Johns Hopkins University, Baltimore, Maryland 21218, while Dr. Sirageldin is Professor in the Department of Political Economy and the Department of Population Dynamics, School of Hygiene and Public Health, The Johns Hopkins University, Baltimore, Maryland 21205.

This is an extensively revised version of a paper originally circulated in March 1979. The authors are indebted to Barb Devaney and Lou Maccini for comments based on a careful reading of the manuscript. They also thank Bruce Hamilton, G. S. Maddala and Charles Mallar for references and helpful discussions. Final thanks to Dave Binko for excellent computational assistance and to S. H. H. Naqavi for invaluable editorial help. Errors are, of course, solely the authors'.

${ }^{1}$ See, in particular, Ryder [48], Nerlove [42], Griliches [19], Ben-Porath [4], Bean [2] and Namboodiri [41].

${ }^{2}$ For preliminary attempts to tackle this problem, see Cochrane and Bean [9] and Khan and Sirageldin[24]. 
Our approach is to assume, to begin with, totally independent preferences for each of the family members. Based on their preferences and their perceptions and knowledge of the (i) household technology, (ii) market prices, and (iii) family income, each relevant member of the family decides on the ideal number and quality of the children he or she wants. The interdependence is built in only at the adjustment stage, i.e. when these ideals get translated into desired additional fertility. As such, this interdependence is assumed for that point in time which has the most relevance for the data, i.e. the time of interview. The principal merit of this approach, it seems to us, is that it avoids the difficulties inherent in aggregation of preferences and furnishes us a framework by means of which such interdependence can be estimated. Such estimates are presented for the 1968 Pakistani data.

However, our paper could be alternatively introduced. The desire for additional children has been the subject of increasing scrutiny by both demographers and economists. ${ }^{3}$ The reason for this interest are two-fold. Firstly, desired additional fertility pertains to short-term sequential decisions for which both the theoretical categories and the available survey data have the most relevance. Secondly, and on a more general level, measures of desired fertility are being increasingly investigated as predictors of actual subsequent fertility. ${ }^{4}$ This paper can be seen as a suggestion that all the studies using the desire for additional children as a dichotomous dependent variable may be subject to a possible omission-of-variables bias due to husband-wife interaction. The point is a simple one. It is that a wife's desire for additional children may be significantly dependent on her husband's desire, and vice versa. Thus omission of one variable as an explanatory factor in the equation for the other may be the source of misleading coefficients for the other exogenous variables. Alternatively put, studies which do not allow for this interaction can only be looked on as yielding reduced-form rather than structural estimates of the parameters.

We illustrate this point by proposing a model suggested by a generalization of the multivariate partial-adjustment hypothesis studied by Mortensen [37] and others. ${ }^{5} \quad$ Such a model is estimated through the use of a two-stage estimator proposed $^{6}$ by Mallar $[31 ; 32]$ and Heckman $[20 ; 21]$ and further studied by Amemiya [1]. We believe that ours is the first application of such an estimating

${ }^{3}$ See Namboodiri [40; 41], Prachuabmoh, Knodel and Alers [44], Rosenzweig and Seiver [46], Stinner and Mader [55], McFadden [36], Knodel and Prachuabmoh [25], Khan and

[46], Stinner and Mader [55], McFadden [36], Knodel and
Sirageldin [24], and Lee and Khan [27], among others.

See Blake [5], Coombs [10], Bumpass [6], Kruegel [26], Freedman, Hermalin and ang [17], Westoff and Ryder [57], and Hermalin, et al. [22], among others.

${ }^{5}$ For empirical applications, see Nadiri and Rosen [38], Schramm [49], and Maccini and Rossana [28], among others. However, as we shall see below, our model departs in an essential way from this literature.

${ }^{6}$ Maddala [30] is an excellent introduction to this area. method in the area of fertility economics and hope to establish that the methodology proposed in this paper can be fruitfully applied to other data sets.

We conclude this introduction by underlining the fact that this estimation of structural parameters is done not merely as an academic exercise but because it has important implications for policy in one of at least three different ways. The first has to do with assessing how variables of particular interest to the policy-make differentially affect husbands and wives. As an example, one could determine, on the basis of such estimates, how successful family planning and educational programmes are when they are solely, or even primarily, aimed at the wife. This would be particularly important if desired additional fertility is a good predictor of subse quent fertility. The second reason why structural estimates are important is that they allow us to gauge the importance of son preference as a factor in fertility decisions at the individual level and, making our first point more specific, they measure the relative strengths of this preference as between husbands and wives The son preference issue has been much discussed, especially in the last five years. ${ }^{7}$ Our third reason has to do with the implications of structural estimates for the design of survey questionnaires. Such estimates underline the importance of interviewing husbands, in addition to wives, at least for a subset of the sample and for answers to at least a selected subset of questions. This is especially important if an analysis of the data obtained from the test questionnaire reveals simultaneity due to husband wife interaction. Indeed, the logic pushes one to request interviews of other members of the family who are considered part of the immediate household. These other members may be the grandparents who are considered part of the household or children older than of a certain age who may be living with their parents.

\section{THE MODEL AND THE ESTIMATION TECHNIQUE}

\section{The Model}

Our model can be looked on as a generalization of the partial adjustment model which is extensively used in applied economics. The basic idea of such a model can be summarized in the following equation:

$$
y(t)-y(t-1)=\lambda(y *(t)-y(t-1)) ; \lambda>0
$$

which says that the discrepancy between the actual and desired values of a partic ular variable is partially adjusted in the next period, the speed of adjustment, $\lambda$, ${ }^{7}$ See Clare and Kiser [8], Dinitz, Dynes and Clarke [13], Etzioni [15], May and Heer
[35], Bumpass and Westoff [7], Markel and Nam [34], Repetto [45], Williamson [59] Cutright, Belt and Scanzoni [11], Markel [33], Westoff and Rindfuss [58], Prachuabmoh [59], [44], McFadden [36], Stinner and Madder [55], Knodel and Prachuabmoh [25], Khan and Sirageldin [24], Rukanuddin [47], Wood and Bean [60] and DeTray [12]- 
being a constant from period to period. If we now append to this hypothesis a theory of how the desired values are determined in each period, i.e.

$$
\mathrm{y}^{*}(\mathrm{t})=\alpha+\beta \mathrm{x}(\mathrm{t})
$$

we obtain

$$
y(t)=\lambda \alpha+(1-\lambda) y(t-1)+\lambda \beta x(t)
$$

An addition of an error term with given assumptions takes us into the discussion of estimators of the parameters in (2.3). For details and further references, see Maddala [29, pp. 142-143] and Griliches [19].

In this paper we propose a generalization of (2.1) along two directions. This is brought out in the following equations.

$$
\begin{aligned}
& \mathrm{y}_{\mathrm{H}}(\mathrm{t})-\mathrm{y}_{\mathrm{H}}(\mathrm{t}-1)=\lambda_{\mathrm{HB}}\left(\mathrm{y}_{\mathrm{HB}}^{*}(\mathrm{t})-\mathrm{y}_{\mathrm{HB}}(\mathrm{t}-1)\right)+\lambda_{\mathrm{HG}}\left(\mathrm{y}_{\mathrm{HG}}^{*}(\mathrm{t})-\mathrm{y}_{\mathrm{HG}}\right. \\
& (\mathrm{t}-1))+\mu_{\mathrm{H}}\left(\mathrm{y}_{\mathrm{W}}(\mathrm{t})-\mathrm{y}_{\mathrm{W}}(\mathrm{t}-1)\right) \ldots \quad \ldots \quad \ldots \quad \ldots \\
& y_{W}(t)-y_{W}(t-1)=\lambda_{W_{B}}\left(y_{W_{B}}^{*}(t)-y_{W_{B}}(t-1)\right)+\lambda_{W_{G}}\left(y_{W_{G}}^{*}(t)-\right. \\
& \left.\mathrm{y}_{\mathrm{WG}}(\mathrm{t}-1)\right)+\mu_{\mathrm{W}}\left(\mathrm{y}_{\mathrm{H}}(\mathrm{t})-\mathrm{y}_{\mathrm{H}}(\mathrm{t}-1)\right) \quad \ldots \quad \ldots \quad \ldots
\end{aligned}
$$

The first generalization consists in replacing the single decision-maker implicit in (2.1) by two interdependent decision-makers, $\mathrm{H}$ and $\mathrm{W}$, with $\mu_{\mathrm{H}}$ and $\mu_{\mathrm{W}}$ as coefficients of interdependence. The second generalization makes each of their decisions consequent on the discrepancy between the desired and actual magnitudes of two variables, distinguished by B and G, rather than of one. As mentioned in the Introduction, the second generalization is readily available in the literature on adjustment cost. Mortenson [37], for example, ${ }^{8}$ studies the system

$$
\frac{\mathrm{dy}}{\mathrm{dt}}=\mathrm{M}\left(\mathrm{y}-\mathrm{y}^{*}\right) \quad \ldots \quad \ldots \quad \ldots \quad \ldots
$$

where $y$ is an $n \times 1$ vector of actual levels, $\mathrm{y}^{*}$ the vector of stationary or equilibrium levels and $\mathrm{M}$ an $\mathrm{n} \times \mathrm{n}$ matrix of adjustment parameters. However, this literature has failed to study our first generalization, i.e. the dependence of $d y_{i} / d t$ on $d y_{j} / d t(i \neq j)$. It is an estimation of this dependence that furnishes the raison d'etre of this paper.
We can now interpret our generalized partial adjustment hypothesis in terms of the categories relevant to this paper. Equation (2.4) states that the husband's demand for additional children depends on (i) the discrepancy between the ideal and actual numbers ${ }^{9}$ of (a) boys and (b) girls, and on (ii) whether the wife wants additional children or not. Equation (2.5) is an analogous statement for the wife. ${ }^{10}$

What remains to be done is to specify the determination of the ideal numbers of boys and girls, i.e. $y_{H B}^{*}(t), y_{W B}^{*}(t), y_{H G}^{*}(t)$ and $y_{W G}^{*}(t)$. For this we fall back on the Chicago-Columbia fertility model; see Schultz [51]. It is outside the scope of this paper to describe this model in any detail, especially since many expository surveys are now available; see Khan [23] for references. It is worth emphasizing, though, that in our treatment we assume that each spouse maximizes his or her utility function subject to the various market and non-market constraints but without taking into account the other spouse's preferences. Thus each spouse decides, independently of the other, his or her ideal number of boys and girls. The interdependence is built in only at the adjustment stage as formalized in equations (2.4) and (2.5). It is also worth remarking that given our focus on the ideal rather than the actual number of children the demand-determined Chicago-Columbia model can be applied with somewhat greater reassurance. ${ }^{11}$ We thus have

$$
\mathrm{y}_{\mathrm{ij}}^{*}(\mathrm{t})=\beta_{\mathrm{ij}} \mathrm{x}_{\mathrm{ij}}(\mathrm{t}) \quad(\mathrm{i}=\mathrm{H}, \mathrm{W} ; \text { and } \mathrm{j}=\mathrm{B}, \mathrm{G}) \quad \ldots \quad \ldots \quad \ldots \quad \ldots
$$

where $\mathrm{x}_{\mathrm{ij}}(\mathrm{t})$ is a vector of exogenous variables emphasized by the theory. Substitution of equation (2.7) into equations (2.4) and (2.5) yields the analogue of equation (2.3) that will be the theoretical starting point of this paper. There are only two difficulties yet to be reckoned with. These have to do with the unsymmetric nature of the variables $y_{i}(t)-y_{i}(t-1), i=H, W$, brought about by the fact that a couple can only increase the stock of its children and that this increase must come, for the majority anyway, in discrete amounts at the rate of one per year. We take account of this by writing $P_{i}(t)=y_{i}(t)-y_{i}(t-1)$ and by interpreting $P_{i}(t)$ as the probability of wanting additional children. Making this a nonlinear function of the variables and parameters of equations (2.4), (2.5) and (2.7), we obtain

\footnotetext{
${ }^{9}$ Note that the actual numbers of boys and girls are, of course, identical for husband and wife.

${ }^{10}$ It is easy to see that a direct application of equation (2.1) to the demand for additional children, as had been initially proposed by Khan [23], is a special case of equation (2.4) obtained by imposing the restrictions $\lambda_{\mathrm{HB}}=\lambda_{\mathrm{HG}}$ and $\mu_{\mathrm{W}}=0$. Wachter[14].
} 


$$
\begin{aligned}
& \mathrm{P}_{\mathrm{H}}(\mathrm{t})=\mathrm{F}_{\mathrm{H}}\left(\lambda_{\mathrm{HB}}, \mathrm{y}_{\mathrm{HB}}(\mathrm{t}-1), \lambda_{\mathrm{HG}}, \mathrm{y}_{\mathrm{HG}}(\mathrm{t}-1), \beta_{\mathrm{HB}}, \mathrm{x}_{\mathrm{HB}}(\mathrm{t}),\right. \\
& \left.\beta_{\mathrm{HG}}, \mathrm{x}_{\mathrm{HG}}(\mathrm{t}), \mu_{\mathrm{H}}, \mathrm{P}_{\mathrm{W}}(\mathrm{t})\right) \\
& P_{W}(t)=F_{W}\left(\lambda_{W_{B}}, y_{W_{B}}(t-1), \lambda_{W_{G}}, y_{W_{G}}(t-1), \beta_{W_{B}}, x_{W_{B}}(t),\right. \\
& \left.\beta_{W G}, x_{W G}(t), \mu_{W}, P_{H}(t)\right)
\end{aligned}
$$

The reader should note the simultaneity between $\mathrm{P}_{\mathrm{H}}(\mathrm{t})$ and $\mathrm{P}_{\mathrm{W}}(\mathrm{t})$ and the inclusion of the number of living boys and girls as explanatory variables in each equation with a negative coefficient.

In conclusion, it should be emphasized that the model as given by equations (2.8) and (2.9) or in its initial form given by equations (2.4) and (2.5) could easily be modified to incorporate the influence exerted on the husband-wife decisions by other members of the family. Thus if the $i^{\text {th }}$ member of the extended family, say the wife's mother, is considered an integral part of the household, we could add a term $\mu_{\mathrm{i}}\left(\mathrm{y}_{\mathrm{i}}(\mathrm{t})-\mathrm{y}_{\mathrm{i}}(\mathrm{t}-1)\right)$ to both (2.4) and (2.5) equations and accordingly derive equations (2.8) and (2.9). For an empirical implementation, one would then need information on $y_{i}(t)-y_{i}(t-1)$, i.e. whether the wife's mother desires additional children for the couple. Given that we do not have such data, we shall ignore this modification in the sequel and content ourselves with including a dummy variable signifying whether the family is nuclear or not.

\section{The Estimation Technique}

The estimation technique that we use comes under the general class of TwoStage Least-Squares Analogues for simultaneous-equation models with limited dependent variables; see Section 5 in Maddala [30]. In the context of our model with dichotomous dependent variables, such estimators have been discussed by Mallar [31] and applied by Mallar [32]. The idea behind such estimators is also clearly implicit in the work of Heckman [20;21] and Amemiya [1], although these authors focus on a two-equation model one of whose equations has a continuous dependent variable. For this reason, we follow the presentation given in Mallar [31] He considers a simultaneous equation model with $\mathrm{G}$ dichotomous endogenous variables with the probability that the $g^{\text {th }}$ dependent variable equals one, denoted by $P_{g i}$, with $g=1, \ldots G$, and $i$ running over the sample. It is assumed that $P_{g i}$ is a "function of the unobserved probabilities from other equations, $\mathrm{P}_{\mathrm{g}}^{*}$, and their corresponding parameters, $\gamma_{\mathrm{g}}$, as well as the parameters, $\beta_{\mathrm{g}}$, and the values for the predetermined explanatory variables, $\mathrm{X}_{\mathrm{g}}$." We thus obtain

$$
P_{g i}=F_{i}\left(X_{g i}, \beta_{g}, P_{g}^{*}, \gamma_{g}\right) g=1, \ldots G \text { and } i=1, \ldots n \ldots
$$

This is precisely the form of our equations (2.6) and (2.7).

Mallar's estimator follows the logic of the two-stage least-squares estimation procedure extensively used in economics, see, for example, [56, pp. $497-500]$. In the first stage, each of the endogenous variables is regressed on all the exogenous variables. For this the probit or logit estimators may be used. From this run one can derive the predicted values for each of the endogenous variables. The relevant predicted values are then used, along with the exogenous variables specific to each equation, as the independent variables in the second probit or logit run. Mallar has proved that under the assumption of independence of the probability distribution functions, "these two-stage estimators have the large-sample maximum likelihood properties of consistency, asymptotic efficiency and asymptotic normality."

In this paper we shall rely solely on probit estimation in each of the two stages. The resulting system of non-linear equations obtained by differentiating the likelihood function is solved by an iterative Newton-Rapheson procedure with 0.00001 as the tolerance level. For a discussion of multi-variate probit analysis, the reader should see, for example, Goldfeld and Quandt [13, chapter 4, p. 128]. For the readers of this journal, we do not need to explain why ordinary least-squares and two-stage least-squares estimating procedures are inapplicable to our model.

\section{DATA SOURCES AND DEFINITIONS OF VARIABLES}

The paper is based on data collected as a part of a national survey, the IMPACT Survey, in West Pakistan (now Pakistan) in 1968-69. For a full description of the survey see Pakistan Family Planning Council [43], Sirageldin and Hardee [54], and Sirageldin [53]. The survey was designed to elicit KAP information, i.e. knowledge and practice of, and attitudes towards family planning. It also obtained pregnancy histories and some details on background socioeconomic variables of a sample of ever-married women in 2,500 households. About half of the households were randomly selected for an independent interviewing of the husbands of currently married women. A total of 1,027 husbands' interview schedules were successfully matched with their wives' schedules. It is on this sub-sample of married couples that the present paper is based. A comparison of the responses of all respondents in the survey with the sub-sample of couples used in this study shows no systematic differences and therefore does not raise major concerns about the representativeness of the sub-sample; for more details on this, see N.M. Shah [52]. The sample used included a cross-section of rural as well as urban couples and was, therefore, more comprehensive than those of most studies conducted on this subject anywhere and the survey was more comprehensive than most surveys in this part of the world.

We now present the variables that are used in the subsequent analysis. We begin with a description of our dependent variables which quantify the demand for additional children 
$\mathrm{AC}(\mathrm{ACH})$ Dummy variable which takes the value of 1 if the wife (husband) wanted any more children and of zero otherwise. The precise question that was asked was, "Do you want any (more) children?"

The reader should note at this point that the variables $\mathrm{AC}$ and $\mathrm{ACH}$ do not distinguish respondents who want only one child from those who want more than one. Further, they have nothing to say about the spacing of these desired additional children.

In keeping with our discussion in Section 2, we attempt to explain the variation in the dependent variable, $\mathrm{AC}$, by a variety of economic, demographic and sociological variables. We present each in turn.

\section{Economic Variables}

ADW (ADH) Dummy variable which takes the value of 1 if the wife (husband) considered her (his) income during the past 12 months adequate or more than adequate, and of zero otherwise.

\section{Demographic Variables}

AF : Age of wife in years.

A : : Age of wife at marriage in years. (Note that all respondents in the sample were married only once.)

DM : Duration of marriage $(=\mathrm{AF}-\mathrm{A})$.

B : Number of living boys.

G : Number of living girls.

\section{Sociological Variables}

EM : Education of husband in years.

EF Dummy variable which takes the value of 1 if the wife is, "literate", and of zero otherwise.

EUF : Dummy variable which takes the value of 1 if the wife has ever used contraceptives, and of zero otherwise.

$\mathrm{U}$ : Dummy variable which takes the value of 1 if the respondent lives in a rural area, and of zero otherwise.
V : Dummy variable which takes the value of 1 if the wife uses a veil, and of zero otherwise.

N : Dummy variable which takes the value of 1 if the respondent has a nuclear family, and of zero otherwise.

Almost all the analysis reported below was carried out on a sub-sample of women who married only once, were currently married and were under 40 years of age at the time of the survey. The age restriction is imposed to give greater prominence to behavioural, rather than biological, variables. We also excluded, in addition, couples, either of whose members could not give a 'yes' or 'no' answer to the question underlying the variables $\mathrm{AC}$ and $\mathrm{ACH}$, reducing our sub -sample to 804 observations. Table 1 presents the means, standard deviations and correlations for all the variables used in the analyses below for this sub-sample.

\section{THE RESULTS}

The results are presented in Tables 2,3 and 4. It is easiest to begin by looking at the first columns in Tables 2 and 3 where the husband-wife interaction terms are totally ignored. These are essentially the probit estimates presented by the authors in 1977 [24] and on which they based their statement that the preference for boys among Pakistani couples is about three times that for girls. In hindsight, we can observe that these are only reduced-form estimates of the parameters in the equations for the demand for additional children.

Columns 2 and 3 in Table 2 and column 2 in Table 3 are a first indication of the wife's demand for additional children being an important determinant of husband's demand and vice versa. However, as the tables specify, these are singlestage probit estimates and hence suffer from the simultaneity bias.

Columns 3 and 4 in Tables 2 and 3 respectively present estimates for our basic simultaneous equation model suggested by equations (2.8) and (2.9). The specification of the model along with the expected signs is brought out in Figure 1. A justification of these signs in terms of the underlying theory and other work can be found in Khan [23]. At any rate, the reader can provide his own commonsense rationalizations.

\begin{tabular}{|c|c|c|c|c|c|c|c|c|c|c|c|c|}
\hline \multirow{3}{*}{$\begin{array}{c}\text { Dependent } \\
\text { Variables }\end{array}$} & \multicolumn{12}{|c|}{ Independent Variables } \\
\hline & \multicolumn{2}{|c|}{ Endogenous } & \multicolumn{8}{|c|}{ Exogenous } & \multirow[b]{2}{*}{ V } & \multirow[b]{2}{*}{$\mathrm{N} \mathrm{U}$} \\
\hline & $\mathrm{AC}$ & $\mathrm{ACH}$ & ADW & $\mathrm{ADH}$ & AF & A & B & G & $\mathrm{EF}$ & EM & & \\
\hline $\begin{array}{l}\mathrm{AC} \\
\mathrm{ACH}\end{array}$ & & + & + & + & - & + & - & - & - & & $?$ & - ? \\
\hline ACA & + & & & + & - & & - & - & & - & $?$ & $-?$ \\
\hline
\end{tabular}


Correlation Matrix for Variables Pertaining

to Pakistani Women Under 40 Years of $\mathrm{Age}^{1,2}$

\begin{tabular}{|c|c|c|c|c|c|c|c|c|c|c|c|c|c|c|}
\hline & $\mathrm{AC}$ & $\mathrm{ACH}$ & ADW & ADH & $\mathrm{AF}$ & A & DM & B & G & EM & $\mathrm{EF}$ & EUF & $\mathrm{U}$ & V \\
\hline $\mathrm{AC}$ & $\begin{array}{c}0.51 \\
(0.50)\end{array}$ & & & & & & & & & & & & & \\
\hline $\mathrm{ACH}$ & 0.40 & $\begin{array}{c}0.67 \\
(0.47)\end{array}$ & & & & & & & & & & & & \\
\hline ADW & -0.04 & 0.05 & $\begin{array}{c}0.61 \\
(0.49)\end{array}$ & & & & & & & & & & & \\
\hline $\mathrm{ADH}$ & -0.05 & 0.06 & 0.18 & $\begin{array}{c}0.60 \\
(0.71)\end{array}$ & & & & & & & & & & \\
\hline $\mathrm{AF}$ & -0.39 & -0.50 & -0.06 & -0.02 & $\begin{array}{l}27.24 \\
(6.47)\end{array}$ & & & & & & & & & \\
\hline A & 0.15 & 0.09 & 0.05 & 0.13 & 0.03 & $\begin{array}{c}16.00 \\
(2.70)\end{array}$ & & & & & & & & \\
\hline DM & -0.41 & -0.50 & -0.08 & -0.07 & 0.91 & -0.37 & $\begin{array}{l}11.23 \\
(6.91)\end{array}$ & & & & & & & \\
\hline B & -0.46 & -0.55 & -0.02 & -0.03 & 0.55 & -0.15 & 0.56 & $\begin{array}{c}1.50 \\
(1.42)\end{array}$ & & & & & & \\
\hline G & -0.30 & -0.36 & -0.05 & 0.01 & 0.55 & -0.18 & 0.58 & 0.25 & $\begin{array}{c}1.40 \\
(1.40)\end{array}$ & & & & & \\
\hline
\end{tabular}

Table 1 -Continued

\begin{tabular}{|c|c|c|c|c|c|c|c|c|c|c|c|c|c|c|}
\hline EM & -0.03 & -0.03 & 0.12 & 0.10 & -0.06 & 0.21 & 0.13 & 0.00 & -0.05 & $\begin{array}{l}25.99 \\
39.58)\end{array}$ & & & & \\
\hline EF & -0.04 & -0.10 & 0.06 & 0.03 & 0.03 & 0.21 & 0.06 & 0.04 & -0.04 & 0.44 & $\begin{array}{c}0.09 \\
(0.29)\end{array}$ & & & \\
\hline EUF & -0.22 & -0.24 & 0.05 & -0.01 & 0.21 & 0.01 & 0.19 & 0.28 & 0.23 & 0.18 & 0.30 & $\begin{array}{c}0.14 \\
(0.35)\end{array}$ & & \\
\hline $\mathrm{U}$ & -0.12 & -0.12 & -0.12 & -0.02 & 0.11 & 0.08 & 0.08 & 0.13 & 0.11 & 0.28 & 0.30 & 0.12 & $\begin{array}{c}0.45 \\
(0.50)\end{array}$ & \\
\hline V & -0.07 & 0.01 & -0.06 & -0.00 & 0.02 & -0.04 & 0.03 & 0.04 & 0.04 & 0.12 & 0.14 & 0.05 & 0.27 & $\begin{array}{c}0.87 \\
(1.51)\end{array}$ \\
\hline & -0.15 & -0.21 & -0.06 & -0.03 & 0.27 & -0.05 & 0.28 & 0.25 & 0.25 & $-0.04-$ & -0.02 & 0.06 & 0.03 & 0.02 \\
\hline
\end{tabular}

${ }^{1}$ Means and Standard Deviations in the diagonal.

${ }^{2}$ Number of cases 804 . 
Table 2

Pakistani Husbands' Demand for Additional Children ${ }^{1}$

Regression No.

\begin{tabular}{|c|c|c|c|c|c|}
\hline \multirow{2}{*}{ Estimator $^{2}$} & (1) & (2) & (3) & (4) & (5) \\
\hline & SSP & $\mathrm{SSP}^{3}$ & SSP & $2 \mathrm{SP}$ & $2 \mathrm{SP}$ \\
\hline Intercept & $\begin{array}{c}3.05 \\
(0.07)\end{array}$ & $\begin{array}{c}2.88 \\
(9.13)\end{array}$ & $\begin{array}{c}2.84 \\
(6.42)\end{array}$ & $\begin{array}{c}0.784 \\
(0.67)\end{array}$ & $\begin{array}{c}2.03 \\
(1.70)\end{array}$ \\
\hline $\mathrm{ADH}$ & $\begin{array}{r}0.125 \\
(1.52)\end{array}$ & $\begin{array}{r}0.103 \\
(1.59)\end{array}$ & - & $\begin{array}{c}0.062 \\
(0.71)\end{array}$ & - \\
\hline ADW & $\begin{array}{r}0.126 \\
(1.07)\end{array}$ & - & - & - & - \\
\hline $\mathrm{AF}$ & $\begin{array}{r}-0.063 \\
(5.13)\end{array}$ & $\begin{array}{r}-0.036 \\
(4.17)\end{array}$ & $\begin{array}{c}-0.051 \\
(2.27)\end{array}$ & $\begin{array}{r}-0.033 \\
(1.84)\end{array}$ & $\begin{array}{r}-0.053 \\
(3.58)\end{array}$ \\
\hline A & $\begin{array}{c}0.012 \\
(0.51)\end{array}$ & $\begin{array}{r}-0.024 \\
(4.58)\end{array}$ & - & - & - \\
\hline DM & - & - & $\begin{array}{r}-0.010 \\
(0.45)\end{array}$ & - & - \\
\hline B & $\begin{array}{r}-0.455 \\
(9.26)\end{array}$ & $\begin{array}{r}-0.311 \\
(7.94)\end{array}$ & $\begin{array}{r}-0.409 \\
(8.17)\end{array}$ & $\begin{array}{r}-0.212 \\
(1.78)\end{array}$ & $\begin{array}{r}-0.275 \\
(1.69)\end{array}$ \\
\hline G & $\begin{array}{r}-0.180 \\
(3.72)\end{array}$ & $\begin{array}{r}-0.085 \\
(2.21)\end{array}$ & $\begin{array}{r}-0.156 \\
(3.24)\end{array}$ & $\begin{array}{r}-0.084 \\
(1.34)\end{array}$ & $\begin{array}{r}-0.104 \\
(1.28)\end{array}$ \\
\hline EM & $\begin{array}{r}0.017 \\
(0.07)\end{array}$ & $\begin{array}{r}-0.002 \\
(1.63)\end{array}$ & - & $\begin{array}{r}-0.001 \\
(0.84)\end{array}$ & - \\
\hline $\mathrm{EF}$ & $\begin{array}{c}-0.610 \\
(2.79)\end{array}$ & - & $\begin{array}{c}-0.534 \\
(2.78)\end{array}$ & 1 & $\begin{array}{r}-0.481 \\
(2.50)\end{array}$ \\
\hline $\mathrm{V}$ & $\begin{array}{r}0.061 \\
(1.52)\end{array}$ & $\begin{array}{c}0.063 \\
(1.73)\end{array}$ & - & $\begin{array}{c}0.028 \\
(0.67)\end{array}$ & - \\
\hline
\end{tabular}

Table 2 - Continued

\begin{tabular}{|c|c|c|c|c|c|}
\hline \multirow{3}{*}{ Estimator $^{2}$} & \multicolumn{5}{|c|}{ Regression No. } \\
\hline & (1) & (2) & (3) & (4) & (5) \\
\hline & SSP & $\mathrm{SSP}^{3}$ & SSP & $2 \mathrm{SP}$ & $2 \mathrm{SP}$ \\
\hline $\mathrm{N}$ & $\begin{array}{r}-0.118 \\
(1.02)\end{array}$ & $\begin{array}{c}-0.144 \\
(1.43)\end{array}$ & - & $\begin{array}{r}-0.066 \\
(0.56)\end{array}$ & - \\
\hline $\mathrm{U}$ & $\begin{array}{c}-0.044 \\
(0.35)\end{array}$ & $\begin{array}{r}-0.151 \\
(1.31)\end{array}$ & - & $\begin{array}{c}-0.046 \\
(0.37)\end{array}$ & \\
\hline $\mathrm{AC}$ & - & $\begin{array}{c}0.558 \\
(4.93)\end{array}$ & $\begin{array}{c}0.393 \\
(3.14)\end{array}$ & $\begin{array}{c}1.772 \\
(2.20)\end{array}$ & $\begin{array}{r}1.386 \\
(1.18)\end{array}$ \\
\hline Twice log & & & & & \\
\hline $\begin{array}{l}\text { likelihood } \\
\text { Degrees of }\end{array}$ & 363 & 525 & 365 & 360 & 356 \\
\hline freedom & 11 & 13 & 6 & 9 & 5 \\
\hline $\begin{array}{l}\text { No. of observa- } \\
\quad \text { tions }\end{array}$ & 804 & 1024 & 804 & 804 & 804 \\
\hline $\begin{array}{l}\text { Mean of Dep. } \\
\text { Var. }\end{array}$ & 0.68 & 0.60 & 0.68 & 0.68 & 0.68 \\
\hline
\end{tabular}

${ }^{1}$ Figures in brackets denote t-statistics.

${ }^{2}$ SSP stands for single-stage probit estimators and 2 SP for 2-stage probit estimators.

Other variables which were not significantly different from zero were dummies relating to husband's occupation and to whether the respondent's house had a private bedroom, electric ity and solid foundation.

The biggest surprise is furnished by column 3 of Table 3 . We find that not a single variable other than the husband's demand for additional children is a significant factor in explaining the wife's demand. Indeed, the highest t-statistic among the remaining determinants is 0.53 . Given these estimates, any conclusions drawn from the figures in columns 1 and 2 would be an obvious source of embarrassment to the investigator.

The situation is somewhat better on the husband's side. In addition to wife's demand, the age of wife, the number of boys, and to a lesser extent, the number of girls are significant determinants of husband's demands. In addition, the coefficients of these variables do not change very much from the estimates in columns 1,2 and 3 of Table 2, at least in comparison with those of the wife. 
Pakistani Wives' Demand for Additional Children ${ }^{1}$

\begin{tabular}{|c|c|c|c|c|c|c|c|}
\hline \multirow{3}{*}{ Estimator } & \multicolumn{6}{|c|}{ Regression No. } & \multirow[b]{2}{*}{ (7) } \\
\hline & (1) & (2) & (3) & (4) & (5) & (6) & \\
\hline & SSP & $\mathrm{SSP}^{2}$ & $2 \mathrm{SP}$ & $2 \mathrm{SP}$ & $2 \mathrm{SP}$ & SSP & SSP \\
\hline Intercept & $\begin{array}{r}0.940 \\
(2.46)\end{array}$ & $\begin{array}{c}1.36 \\
(4.26)\end{array}$ & $\begin{array}{c}-1.21 \\
(1.52)\end{array}$ & $\begin{array}{c}-1.93 \\
(7.14)\end{array}$ & $\begin{array}{c}-1.54 \\
(1.01)\end{array}$ & $\begin{array}{c}0.78 \\
(2.13)\end{array}$ & $\begin{array}{c}0.33 \\
(2.05)\end{array}$ \\
\hline $\mathrm{ADH}$ & $\begin{array}{r}-0.139 \\
(1.71)\end{array}$ & & & $\begin{array}{r}-0.154 \\
(1.91)\end{array}$ & $\begin{array}{r}-0.143 \\
(1.88)\end{array}$ & $\begin{array}{r}-0.160 \\
(1.94)\end{array}$ & $\begin{array}{r}-2.208 \\
(2.48)\end{array}$ \\
\hline ADW & $\begin{array}{r}0.164 \\
(1.56)\end{array}$ & $\begin{array}{r}-0.192 \\
(1.98)\end{array}$ & $\begin{array}{c}-0.33 \\
(0.28)\end{array}$ & & & - & \\
\hline AF & $\begin{array}{r}-0.032 \\
(2.92)\end{array}$ & $\begin{array}{r}-0.027 \\
(3.19)\end{array}$ & $\begin{array}{r}-0.002 \\
(0.13)\end{array}$ & & & $\begin{array}{r}-0.030 \\
(2.82)\end{array}$ & \\
\hline A & $\begin{array}{c}0.062 \\
(2.92)\end{array}$ & $\begin{array}{r}-0.005 \\
(0.94)\end{array}$ & $\begin{array}{r}0.006 \\
(0.53)\end{array}$ & & & $\begin{array}{r}0.060 \\
(2.95)\end{array}$ & \\
\hline DM & & - & - & $\begin{array}{r}0.001 \\
(0.36)\end{array}$ & $\begin{array}{r}-0.001 \\
(0.34)\end{array}$ & & $\begin{array}{r}-0.059 \\
(7.33)\end{array}$ \\
\hline
\end{tabular}

Table 3-Continued

$\begin{array}{lrrr}\text { B } & -0.391 & -0.324 & -0.060 \\ & (8.27) & (8.06) & (0.53) \\ \text { G } & & & \\ & -0.140 & -0.135 & -0.025 \\ & (3.00) & (3.37) & (0.41) \\ \text { EM } & -0.488 & -0.001 & \\ & (2.46) & (0.66) & \\ \text { EF } & 0.070 & - & -0.016 \\ & (0.34) & & (0.08) \\ & & & \\ \text { V } & -0.046 & -0.064 & -0.008 \\ & (1.28) & (1.80) & (0.20) \\ & & & \\ \text { N } & 0.021 & 0.069 & 0.008 \\ & (0.20) & (0.71) & (0.07) \\ & & & \\ \text { U } & -0.138 & -0.109 & -0.021 \\ & (1.25) & (1.01) & (0.18)\end{array}$

EUF

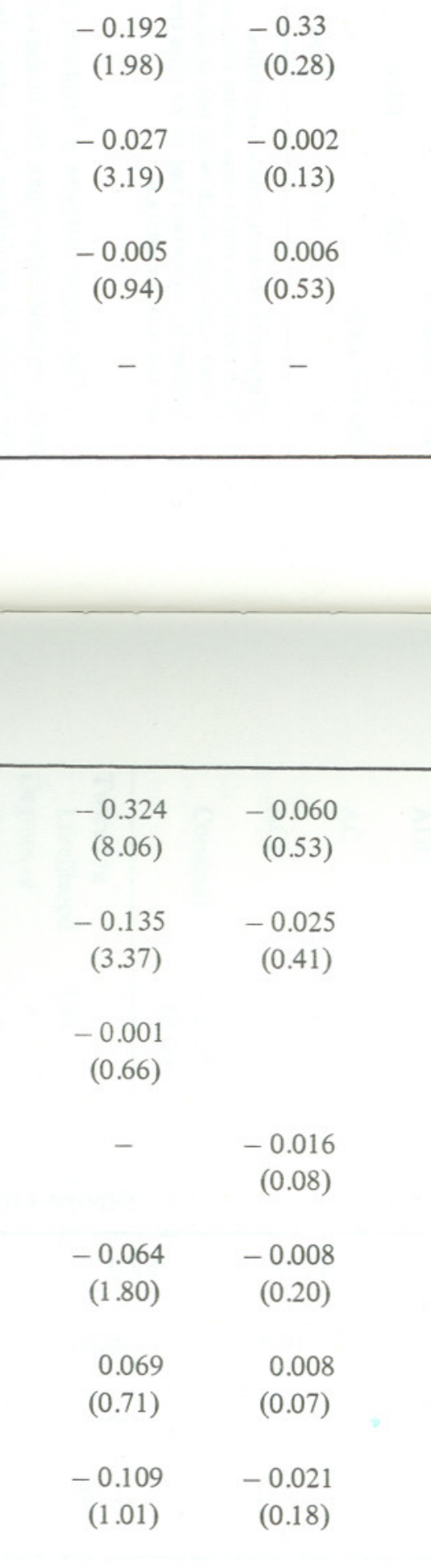

. 
Ever-Use of Family Planning Methods by Pakistani Women Under 40 Years of Age ${ }^{1}$

\begin{tabular}{|c|c|c|c|c|}
\hline \multirow{3}{*}{ Estimator $^{2}$} & \multicolumn{4}{|c|}{ Regression No. } \\
\hline & (1) & (2) & (3) & (4) \\
\hline & $2 \mathrm{SP}$ & SSP & SSP & SSP \\
\hline \multirow[t]{2}{*}{ EM } & 0.003 & 0.003 & 0.003 & 0.003 \\
\hline & $(1.87)$ & $(1.70)$ & (1.91) & $(1.75)$ \\
\hline \multirow[t]{2}{*}{$\mathrm{EF}$} & 1.135 & 1.148 & 1.112 & 1.124 \\
\hline & $(5.76)$ & $(5.80)$ & $(5.66)$ & $(5.67)$ \\
\hline \multirow{2}{*}{$\mathrm{AF}$} & - & -0.008 & -0.006 & -0.008 \\
\hline & & $(0.52)$ & $(0.39)$ & $(0.31)$ \\
\hline \multirow[t]{2}{*}{ B } & 0.261 & 0.235 & 0.247 & 0.270 \\
\hline & $(2.10)$ & $(4.48)$ & $(4.58)$ & $(5.26)$ \\
\hline \multirow[t]{2}{*}{ G } & 0.227 & 0.217 & 0.224 & 0.238 \\
\hline & $(3.14)$ & $(4.28)$ & $(4.41)$ & $(4.58)$ \\
\hline \multirow[t]{2}{*}{$\mathrm{ADH}$} & - & -4.857 & -0.033 & -0.037 \\
\hline & & $(0.53)$ & $(0.36)$ & $(0.40)$ \\
\hline \multirow[t]{2}{*}{$\mathrm{AC}$} & 0.028 & -0.278 & & - \\
\hline & $(0.3)$ & (1.87) & & \\
\hline \multirow[t]{2}{*}{$\mathrm{ACH}$} & & & -0.125 & - \\
\hline & & & $(0.81)$ & \\
\hline \multirow[t]{2}{*}{ Constant } & -2.18 & -1.75 & -1.88 & -2.27 \\
\hline & (3.09) & $(4.47)$ & $(4.53)$ & (4.72) \\
\hline \multicolumn{5}{|l|}{ Twice log } \\
\hline Likelihood & 139 & 143.02 & 140.15 & 140 \\
\hline \multicolumn{5}{|l|}{ Degrees of } \\
\hline Freedom & 5 & 7 & 7 & 7 \\
\hline \multicolumn{5}{|l|}{ No. of Observa- } \\
\hline tions & 804 & 804 & 804 & 804 \\
\hline \multicolumn{5}{|l|}{ Mean of Dep. } \\
\hline Var. & 0.17 & 0.17 & 0.17 & 0.17 \\
\hline
\end{tabular}

${ }^{1}$ See footnotes 1 and 2 of Table 2. 
For our next set of results, the reader should refer to our generalization of the partial adjustment hypothesis - specifically equation (2.5). T. P. Schultz [50] has convincingly argued that the speeds of adjustment parameterized by $\lambda$ 's should be expected to depend on contraceptive use. Thus it seems natural to include such a variable in equation (2.9). Unfortunately, current rates of contraceptive use are very low in Pakistan (6 percent in our sample as a whole). However, this is not the case with EUF, a variable formalizing whether contraceptive methods were ever used. We thus decided to include EUF as an independent variable in the wife's demand for additional children.

Once we use EUF as a proxy for the current use of contraceptive methods, consistency demands that we also recognize that EUF may be determined by AC. Stated simply, a wife uses or does not currently use contraceptive methods depending on whether she wants an additional child or not.

Based on the estimates of our Model A and on the above ideas relating to contraceptive use, we formulated a three-equation simultaneous-equation model. This is given as Figure 2.

\begin{tabular}{|c|c|c|c|c|c|c|c|c|c|c|}
\hline \multirow{3}{*}{$\begin{array}{l}\text { Dependent } \\
\text { Variables }\end{array}$} & \multicolumn{10}{|c|}{ Independent Variables } \\
\hline & \multicolumn{2}{|c|}{ Endogenous } & \multicolumn{8}{|c|}{ Exogenous } \\
\hline & $\mathrm{AC}$ & $\mathrm{ACH}$ & EUF & $\mathrm{ADH}$ & $\mathrm{AF}$ & DM & B & G & EF & EM \\
\hline $\mathrm{ACH}$ & + & & & & - & & - & - & - & \\
\hline $\mathrm{AC}$ & & + & - & + & & - & & & & \\
\hline EUF & - & & & & & & + & + & + & + \\
\hline
\end{tabular}

Figure 2 : Expected Signs : Model B

The estimates of the parameters in the equation for $\mathrm{ACH}$ are given in column 5 of Table 2. There are no real surprises here. Education of the wife is a much more important determinant of the husband's demand than his own education. Such a finding is frequent in the related literature and is explained by viewing wife's education more as a proxy for the value of her time than as a parameter of tastes or social norms. We remind the reader that our data set has no information on women's wage rates. The second change in column 5 has to do'with the decrease in the t-statistic relating to AC. Strictly speaking, the coefficient of AC is no longer significantly different from zero. We thus have an indication of a recursive structure here. The importance of the inclusion of $\mathrm{AC}$ can be gauged by comparing columns 1 and 5 of Table 3.
Column 4 of Table 3 presents estimates for the parameters in the equation for AC. The coefficient of EUF is not significantly different from zero. In addition to $\mathrm{ACH}$, the only other variable relevant for $\mathrm{AC}$ is whether the husband considers his income adequate or not. Putting these findings together with those of the husband, the picture emerges that the husband's attitudes are a sole determinant for the wife's demand for additional children and that the relationship does not run the other way. The husband's demand is affected by objective indices such as age and education of wife and the number of boys and girls.

Moving on to the last relationship of Model B, that for EUF, we find that all the coefficients have expected signs but that the coefficient of $\mathrm{AC}$ is not significantly different from zero; see column 1 in Table 4. Thus, it seems that the AC - EUF interrelationship is absent from our data set. However, it is worth emphasizing that this finding is a consequence of using the two-stage estimating procedure. Single-stage runs are reported as columns 2, 3 and 4 in Table 4 , the last column being the reduced-form run. Similarly, single-stage estimates of the AC relationship are given in columns 6 and 7 of Table 3. Column 5 of the same table is a hybrid in the sense that it is based on the predicted value of EUF but not on that of ACH.

\section{CONCLUDING REMARKS}

In conclusion, our paper offers a theoretical model for the incorporation of intrafamily interaction in the "family's desire" for additional children. For a sample of Pakistani couples, the paper limits itself to husband-wife interaction and offers estimates of these interaction terms. Such terms have been explicitly or implicitly ignored in the literature using the "desire for additional children" as a dependent variable. This is, of course, not to argue that such interaction terms will be significant and will affect the coefficients of the other exogenous variables; we only suggest that this insignificance cannot be assumed a priori. One must also mention the other possibilities in which only the interaction terms have coefficients significantly different from zero. Such a case would be a consequence, if not of a common utility function, at least of a very high degree of agreement between the spouses as regards desired additional fertility and would leave the investigator no recourse other than that of relying on reduced-form estimates. But, here again, such a situation cannot be assumed a priori.

Our paper also has a bearing on the statement frequently encountered in the applied literature that development of sophisticated estimation techniques is a waste of resources when the data bases are crude, as they typically are in less developed countries. It is precisely the crudity of the data in terms of a yes-no response that requires, in our context, an advanced estimating method.

Finally, the model developed in this paper may have a possible bearing on the measurement of relative power each spouse exercises over the other in terms of fertility decisions, or more generally, the structure of the decision process in various 
types of family units, e.g. from nuclear to various degrees of extended family types. For a recent review, see Beckman [3] .

\section{REFERENCES}

1. Amemiya, T. "The Estimation of a Simultaneous Equation Generalized Probit Model”. Econometrica. Vol. 46. 1978. pp. $1193-1205$.

2. Bean, F. D. Review of Economics of the Family: Marriage, Children and Human Capital (edited by Theodore W. Schultz). Demography. Vol. 12. 1975. pp. $557-561$.

3. Beckman, L. J. "Couples' Decision-Making Processes Regarding Fertility". In K. E. Taeuber, L. L. Bumpass and J. A. Sweet (eds.), Social Demography. New York: Academic Press. 1978. pp. $57-81$.

4. Ben-Porath, Y. "Notes on the Microeconomics of Fertility". International Social Science Journal. Vol. XXVI. 1974. pp. 5302 - 5314.

5. Blake, J. "Can We Believe Recent Data on Birth Expectations in the United States?” Demography. Vol. 11.1974. pp. 25 - 44.

6. Bumpass, L. L. "Comment on Judith Blake's 'Can We Believe Recent Data on Birth Expectations in the United States?' " Demography. Vol. 12. 1975. pp. $155-156$

7. Bumpass, L. L., and C. F. Westoff. The Later Years of Childbearing. New Jersey: Princeton University Press. 1970. pp.93-94.

8. Clare, J. E., and C. V. Kiser. "Preference for Children of a Given Sex in Relation to Fertility". Milbank Memorial Fund Quarterly. Vol. 29. October 1951. pp. $440-492$.

9. Cochrane, S. H., and F. D. Bean. "Husband-Wife Differences in the Demand for Children". Journal of Marriage and the Family. May 1976 pp. $297-307$.

10. Coombs, L. C. "The Measurement of Family Size Preferences and Subsequent Fertility”. Demography. Vol. 11. 1974. pp. $587-611$.

11. Cutright, P., S. Belt and J. Scanzoni. "Gender Preference, Sex Predetermination and Family Size in the United States". Social Biology. Vol. 21, Fall 1974. pp. $242-248$.

12. DeTray, D. "Son Preference in Pakistan: An Analysis of Intentions Versus Behavior". The Rand Corporation. 1978. Mimeo.

13. Dinitz, S., R. R. Dynes and A. C. Clarke. "Preferences for Male or Female Children: Traditional or Affectional". Marriage and Family Living. May 1954. pp. $128-130$.

14. Easterlin, R. E., R. A. Pollak and M. L. Wachter. "Toward a More General Economic Model of Fertility Determination: Endogenous Preferences and Natural Fertility". Paper given at the National Bureau of Economic
Research Conference on Economic and Demographic Change in Less Developed Countries, New York. 1976.

15. Etzioni, A. "Sex Control, Science and Society". Science. Vol. 161. 13 September, 1968. pp. $1107-1112$.

16. Freedman, D. S., R. Freedman and P. K. Whelpton. "Size of Family and Preference for Children of Each Sex". American Journal of Sociology, Vol. 66. 1960. pp. $141-146$.

17. Freedman, R., A. I. Hermalin and Mung-Chang. "Do Statements About Desired Family Size Predict Fertility? The Case of Taiwan 1967 - 1970" Demography. Vol. 12,1975. pp. $407-416$.

18. Goldfeld, S. M., and R.E. Quandt. Non-Linear Methods in Econometrics. Amsterdam: North Holland Publishing Co. 1972.

19 Griliches, Z. "Distributed Lags : A Survey”. Econometrica. Vol. 35. 1967. pp. $16-49$.

20. Heckman, J. J. "Simultaneous Equation Models with Continuous and Discrete Endogenous Variables and Structural Shifts". In S. Goldfeld and R. Quandt, Studies in Non-linear Estimation. Cambridge, Mass. (USA): Ballinger Publishing Co. 1976.

21. Heckman, J. J. "Dummy Endogenous Variables in a Simultaneous Equation System". Econometrica. Vol. 46. 1978. pp.931-960.

22. Hermalin, A., R. Freedman, T. H. Sun and M-C. Chang. "Do Intentions Predict Fertility? The Experience in Taiwan, 1967-74". Studies in Family Planning. Vol. 10, No. 3. 1979. pp.75-95.

23. Khan, M. Ali. "Relevance of Human Capital Theory to Fertility Research: Comparative Findings for Bangladesh and Pakistan". Research in Human Capital and Development. Vol. 1. 1979. pp. $1-42$.

24. Khan, M. Ali, and I. Sirageldin. "Son Preference and the Demand for Additional Children in Pakistan". Demography. Vol. 14. 1977. pp. 481 - 495. Reprinted in B. Boulier (ed.), Household Models of Economic Demographic Decision Making. Belgium : IUSSP Press. 1980.

25. Knodel, J., and V. Prachuabmoh. "Preferences for Sex of Children in Thailand: A Comparison of Husbands' and Wives' Attitudes". Studies in Family Planning. Vol. 7.1976. pp. 137 - 143.

26. Kruegel, D. L. "Further Comment on J. Blake's 'Can We Believe Recent Data on Birth Expectations in the United States?' " Demography. Vol. 12. 1975. pp. $157-161$.

27. Lee, C., and M. M. Khan. "Factors related to the Intention to Have Additional Children in the United States: A Reanalysis of Data from the 1965 and 1970 National Fertility Studies". Demography. Vol. 15. 1978. pp. $337-344$. 
28. Maccini, L. J., and R. Rossana. "A Modified Flexible Accelerator Model of Finished Goods Inventory Investment: An Analysis of Adjustment Speeds". Baltimore: Johns Hopkins University. 1980. Preprint.

29. Maddala, G.S. Econometrics. New York: McGraw-Hill Book Co. 1977.

30. Maddala, G. S. "Selectivity Problems in Longitudinal Data". Annales de l" Insee. Nos. 30-31. April-September 1978. pp. $423-450$.

31. Mallar, C. D. "The Estimation of Simultaneous Probability Models". Econometrica. Vol. 45. 1977. pp. 1717 - 1722.

32. Mallar, C. D. "Estimating a Simultaneous Probability Model: The School and Labor Force Decisions of Youths". Proceedings of the Business and Economic Statistics Section, American Statistical Association. New York. 1976. pp. $448-450$.

33. Markel, G. "Sex Ratio at Birth: Values, Variance and Some Determinants" Demography. Vol. 11. February 1974. pp. $131-142$.

34. Markel, G., and C. B. Nam. "Sex Predetermination: 1st Impact on Fertility" Social Biology. Vol. 18. March 1971. pp. $73-78$.

35. May, D., and D. Heer. "Son Survivorship, Motivation and Family Size in India: A Computer Simulation”. Population Studies. Vol. 22. July 1968. pp. $199-210$.

36. McFadden, D. "Comments on 'Estimation of a Stochastic Model of Reproduction: An Econometric Approach' ". In N. E. Terleckyi (ed.), Household Production and Consumption. New York: Columbia University Press. 1975.

37. Mortenson, D. T. "Generalized Costs of Adjustment and Dynamic Factor Demand Theory". Econometrica. Vol. 41. 1973. pp. $657-665$.

38. Nadiri, M. I., and S. Rosen. A Disequilibrium Model of the Demand for Factors of Production. New York: Columbia University Press. 1973.

39. Namboodiri, N. K. "Some Observations on the Economic Framework for Fertility Analysis". Population Studies. Vol. 26. 1972. pp. 185 - 206

40. Namboodiri, N. K. "Which Couples at Given Parities Expect to have Additional Births? An Exercise in Discriminant Analysis". Demography. Vol. 11, No. 1. 1974. pp. $45-56$.

41. Namboodiri, N. K. Review of Economics of the Family: Marriage, Children and Human Capital (edited by Theodore W. Schultz). Demography. Vol. 12. 1975. pp. $551-556$.

42. Nerlove, M. "Household and Economy: Toward a New Theory of Population and Economic Growth". Journal of Political Economy. Vol. 82, No. 2. Part II. March/April 1974.

43. Pakistan Family Planning Council. Survey Design and Development: National Impact Survey. Lahore: Training, Research and Evaluation Centre (TREC). 1969.
44. Prachuabmoh, V., John Knodel and J. Alers. "Preference for Sons, Desire for Additional Children and Family Planning in Thailand". Journal of Marriage and the Family. Vol.36. 1974. pp. $601-614$.

45. Repetto, Robert. "Son Preference and Fertility Behavior in Developing Countries". Studies in Family Planning. Vol. 4. 1972. pp. $70-76$.

46. Rosenzweig, M. R., and D. A. Seiver. "Comment on N. K. Namboodiri's 'Which Couples at Given Parities Expect to have Additional Birth? An Exercise in Discriminent Analysis' ". Demography. Vol. 12, No. 4. 1975. pp. $665-668$.

47. Rukanuddin, R. A. "The Effect of Sex Preference and Infant and Child Mortality on Fertility Behaviour of Couples in Pakistan". Unpublished Ph. D. dissertation, Johns Hopkins University, Baltimore, Maryland. 1975.

48. Ryder, N. "Comment on Willis's Paper". Journal of Political Economy. Vol. 81. 1973. pp. $246-267$.

49. Schramm, R. "The Influence of Relative Prices, Production Conditions and Adjustment Costs on Investment Behavior". Review of Economic Studies. Vol. 37. 1970. pp. $361-376$.

50. Schultz, T. P. "An Economic Interpretation of the Decline in Fertility in a Rapidly Developing Country: Consequences of Development and Family Planning". Economic Growth Centre Discussion Paper No. 258, Yale University, New Haven, Conn. (USA). 1977.

51. Schultz, T. W. (ed.). Economics of the Family: Marriage, Children and Human Capital. Chicago: University of Chicago Press. 1974.

52. Shah, Nasra Makhdoom. "Interspousal Communication and Agreement at Variables in the Study of Family Planning". Unpublished Ph. D. dissertation, Johns Hopkins University, Baltimore, Maryland (USA). 1974.

53. Sirageldin, I. "The Survey Method in Family Planning Research and Evaluation". In J. F. Kantner and Lee McCaffrey (eds.), Population and Development in Southeast Asia. Lexington, Massachusetts: Lexington Books. 1975

54. Sirageldin, I., and G. Hardee. "A Flexible Interaction Model for Analyzing Sample Survey Data for Planning and Evaluation of Fertility Control in Pakistan”. CENTO Symposium on Demographic Statistics, Karachi (1968). (Published by Office of United States Economic Coordinator for CENTO Affairs; August 1970.)

55. Stinner, W. F., and P. D. Mader. "Sons, Daughters or Both?: An Analysis of Family Sex Composition Preferences in the Philippines". Demography. Vol. 12. 1975. pp. $67-79$.

56. Theil, Henry. Principles of Econometrics. NewYork: John Wiley and Sons. 1971. 
57. Westoff, C. F., and N. B. Ryder. "The Predictive Validity of Reproductive Intentions". Demography. Vol. 14. 1977. pp. $431-454$.

58. Westoff, C. F., and R. R. Rindfuss. "Sex Preference in the United States: Some Implications”. Science. Vol. 184. 10 May 1974. pp. 633 - 636.

59. Williamson, N. E. "Preference for Boys Around the World". Unpublished Ph. D. dissertation, Harvard University, Cambridge, Massachusetts. 1973.

60. Wood, C. H., and F. D. Bean. "Offspring Gender and Family Size: Implications from a Comparison of Mexican Americans and Anglo Americans". Journal of Marriage and Family. Vol. 39. 1977. pp. 129- 139. 